Bioscientia Medicina: Journal of Biomedicine \& Translational Research

Journal Homepage: www.bioscmed.com

\title{
Accuracy of Cell-Free DNA (cfDNA) in Colorectal Cancer Diagnosis
}

\section{Anjab Akmal Sya'roni ${ }^{*}$, Suyata ${ }^{2}$, Imam Supriyanto ${ }^{2}$, Vidi Orba Busro², Ayus Astoni², Mediarty Shahrir ${ }^{3}$, Taufik Indrajaya ${ }^{4}$, Erial Bahar ${ }^{5}$}

1 Trainee of Gastroentero Hepatology, Department of Internal Medicine, Faculty of Medicine, Universitas Sriwijaya, Palembang, Indonesia

${ }^{2}$ Division of Gastroentero Hepatology, Department of Internal Medicine, Faculty of Medicine, Universitas Sriwijaya, Palembang, Indonesia

${ }^{3}$ Division of Hematology and Oncology, Department of Internal Medicine, Faculty of Medicine, Universitas Sriwijaya, Palembang, Indonesia

${ }^{4}$ Division of Cardiology, Department of Internal Medicine, Faculty of Medicine, Universitas Sriwijaya, Palembang, Indonesia

${ }^{5}$ Department of Anatomy, Faculty of Medicine, Universitas Sriwijaya, Palembang, Indonesia

\section{A R T I L L I N F O}

Keywords:

Colorectal cancer

cell-free DNA

cfDNA

\section{*Corresponding author:}

Anjab Akmal Sya'roni

\section{E-mail address:}

\section{a syaroni@yahoo.com}

All authors have reviewed and approved the final version of the manuscript.

\section{A B S T R A C T}

Background: The requirement for malaria elimination to be recognized is to prove Background. Colorectal cancer is the third most common type of cancer following lung and breast cancer with the second most common cause of cancer-related death globally. Delayed diagnosis due to limited source and modality to perform early diagnosis lead to advanced-stage condition which contributes to higher morbidities and mortalities. Recent diagnosis of colorectal cancer depends on biopsy of suspected tissues, either obtained surgically or per colonoscopy. Colorectal cancer detection through cell-free DNA measurement allowing small-size cancer being detected even in early stage. cfDNA originated from derivates of increased and abnormality apoptosis-necrosis pathway from cancer lesion, therefore can be managed as specific tumor marker. Methods: Diagnostic test was performed at the Gastroentero Hepatology Outpatient Unit and Internal Medicine Inpatient Unit of Dr. Mohammad Hoesin General Hospital Palembang from March to June 2021. Data processing and analysis using SPSS version 26.0 for Windows. Results: Among 50 subjects included, 39 subjects $(78 \%)$ are diagnosed with colorectal cancer, whereas 11 subjects $(22 \%)$ as control. The median of cfDNA result is $59,71 \mathrm{ng} / \mathrm{mL}$ with $92,3 \%$ sensitivity, 90,9\% specificity, 95,2\% positive predictive value, $82,3 \%$ negative predictive value, and $92,4 \%$ accuracy rate. Combination the measurement of cfDNA, CEA, and CA19-9 appears to have better AUC instead of single measurement.

Conclusion: The study reveals that cell-free DNA (cfDNA) demonstrated a very promising accuracy rate in diagnosing colorectal cancer.

https://doi.org/10.32539/bsm.v5i11.422

\section{Introduction}

Colorectal cancer is the third most common type of cancer globally after lung cancer and breast cancer, and is the second leading cause of cancer death in the world. ${ }^{1}$ In Indonesia, GLOBOCAN 2020 data states that the incidence of new cases of colorectal cancer is in third place, namely $8.6 \%$. In men, colorectal cancer is the second most common cancer (11.9\%) and in women it is the fourth most common cancer (5.8\%). ${ }^{1}$ Technological and diagnostic developments in the last two decades have led to an increase in average life expectancy in colorectal cancer patients, although mortality rates are still high and are generally associated with late diagnosis. ${ }^{2}$ There is limited ability to screen, so that patients come in an advanced stage or general condition that has greatly decreased due to delays in diagnosis, causing treatment to be more complex and risky. As a result, morbidity and mortality will be greater. Therefore, early diagnosis is very important for the survival of patients, because patients detected in stages I-II have a survival rate of up to 90\%.3 This number dropped drastically in stage IV, which was only about $14 \%$. Detection of cancer- 
associated DNA abnormalities through peripheral blood allows small colorectal cancers to be detected at an early stage compared with currently available tumor markers, fecal occult blood tests, and currently available imaging modalities. ${ }^{4}$

In patients with cases of malignancy, identification of DNA in serum or plasma is referred to as circulating free DNA (cfDNA). cfDNA is derived from increased and abnormal apoptotic-necrosis pathways in cancerous lesions. This abnormal DNA degradation and secretion causes an increase in the levels of fragmented DNA of various sizes, and can be identified by biomolecular examination techniques in the blood. Tumor cells that release cfDNA are able to provide an overview of the genetic and epigenetic changes of the tumor origin that make cfDNA has an important role in the theory of genometastases. Several cfDNA diagnostic tests in colorectal cancer have shown conflicting results. Current studies detect cfDNA with a variety of different primary lesions. The study by Wang et al compared several primers in diagnosing colorectal cancer and found that the Alu and GADPHgenes (glyceraldehyde3-phosphate dehydrogenase) are sensitive markers in diagnosing colorectal cancer. Alu is a short strand of DNA derived from the action of restriction endonucleases by Arthrobacter luteus (Alu). The Alu sequence is element transposable the most abundant, containing more than one million copies scattered throughout the human genome. Umetani et al found two primers new, ALU247 and ALU115, which were used in quantitative PCR detection of long and short chain DNA fragments. This study found a correlation between tumor progression and the ratio of long-shortchain DNA fragments in the blood of colorectal cancer patients using quantitative PCR of Alu sequences, the most frequently repeated sequence in the human genome. Detection of cfDNA with Alu marker can be a potential biomarker in screening and early detection of colorectal cancer. Meanwhile, other studies such as ElGayar's study showed that cfDNA levels did not provide a good enough accuracy test result in diagnosing colorectal cancer. This difference may occur due to differences in methods and racial differences in the patient sample studied. ${ }^{3}$

\section{Methods}

This type of research is a diagnostic test. The research was conducted at the Gastroentero Hepatology Polyclinic and Inpatient Department of Internal Medicine, Dr. Mohammad Hoesin Palembang which was carried out from March 2021 - June 2021. The research sample was taken by non- probability consecutive sampling. All research samples that meet the inclusion criteria from December 2020 - March 2021, as many as 50 samples, were included in the study sequentially. The samples were then divided into two groups according to the histopathological findings found, namely the colorectal cancer group or the group without colorectal cancer. The inclusion criteria: All colorectal cancer suspects who came to the Gastroentero Hepatology Polyclinic and Inpatient Department of Internal Medicine, Dr. Mohammad Hoesin Palembang, all colorectal cancer patients who have never undergone chemotherapy and/or radiotherapy, are willing to participate in the study by signing anform informed consent.

Geographical basic data retrieval in the form of age, gender, education level and occupation. The collection of clinical baseline data which included a family history of cancer, a history of comorbid diseases, a history of habits related to colorectal cancer (smoking, alcoholism, and diet), clinical symptoms related to colorectal cancer and body mass index. Blood specimen collection for examination at the Eureka Research Laboratory, Palembang, Indonesia, which includes complete routine blood (hemoglobin, leukocytes, platelets, blood chemistry (kidney function, liver function), colorectal cancer biomarkers (CEA, CA19-9), and cfDNA, in accordance with the protocols and procedures of the Eureka Research Laboratory.

The data that has been collected is processed using the SPSS version 26.0 program which will be displayed in the form of narration, tables and graphs. Numerical data is expressed as the appropriate median, minimum and maximum. Qualitative data is expressed as frequency and percentage for quantitative data that are not normally distributed, the comparison between the two groups was carried out using the Mann-Whitney test (non-parametric $\mathrm{t}$ test). The comparison between 
the 3 groups was carried out using the Kruskal-Wallis test and the post-Hoc "Schefe test" was used for pairwise comparisons. Spearman-rho is used to test the correlation between numerical variablesCurve Receiver Operating Characteristic (ROC) plotted for evaluation of the diagnostic test. All tests have two sides. The $\mathrm{p}$ value $<0.05$ was considered significant.

\section{Results}

Research variables included in the general characteristics of this study consisted of age, gender, body mass index (BMI) group, history of low fiber diet, smoking history, and alcohol history. Of the 50 research subjects, the average age of the patients was $53.14 \pm 10.18$ years. The older group without cancer had an older mean age, although the mean difference was not significant. The group of patients with cancer had a mean age of $48.91 \pm 13$ years and the group of patients without a history of KKSV had a mean age of $54.33+9.09$. As many as 25 (50\%) patients were male and males were more commonly found in the cancer group, while females were more commonly found in the non-cancer group. As many as $40 \%$ of patients underweight and cancer group tend to be more underweight. There was no difference in gender and nutritional status in the two groups of research subjects. Based on the history of risk factors, it is known that most of the study participants have a lowfiber diet, do not smoke, and do not consume alcohol. The risk factors for consuming a low-fiber diet were found to be significantly more in the adenocarcinoma group. Meanwhile, there was no significant difference between smoking history and alcohol history in the two groups.

Table 1. General characteristics of research subjects

\begin{tabular}{|c|c|c|c|c|}
\hline & $\begin{array}{c}\text { Subjects (n = } \\
50, \%)\end{array}$ & $\begin{array}{c}\text { cancer } \\
(n=39, \%)\end{array}$ & $\begin{array}{l}\text { without cancer } \\
(\mathrm{n}=11 \%)\end{array}$ & $\mathbf{p}$ \\
\hline Age (years) * & $53.14 \pm 10.18$ & $48.91 \pm 13$ & $54.33 \pm 9.09$ & $0.12^{1}$ \\
\hline \multicolumn{5}{|l|}{ Gender } \\
\hline $\begin{array}{l}\text { Male } \\
\text { Female }\end{array}$ & $\begin{array}{l}25(50 \%) \\
25(50 \%)\end{array}$ & $\begin{array}{l}20(51.3 \%) \\
19(48.7 \%)\end{array}$ & $\begin{array}{l}5(45.5 \%) \\
6(54.5 \%)\end{array}$ & $0.73^{2}$ \\
\hline \multicolumn{5}{|c|}{ Nutritional Status } \\
\hline $\begin{array}{l}\text { Underweight } \\
\text { Normoweight }\end{array}$ & $\begin{array}{l}20(40 \%) \\
30(60 \%)\end{array}$ & $\begin{array}{l}18(46.2 \%) \\
21(53.8 \%)\end{array}$ & $\begin{array}{l}2(18.2 \%) \\
9(81.8 \%)\end{array}$ & $0.16^{3}$ \\
\hline \multicolumn{5}{|l|}{ Low Fiber Diet } \\
\hline $\begin{array}{l}\text { Yes } \\
\text { None }\end{array}$ & $\begin{array}{c}46(92 \%) \\
4(8 \%)\end{array}$ & $\begin{aligned} 38 & (97.4 \%) \\
1 & (2.6 \%)\end{aligned}$ & $\begin{array}{l}8(72.7 \%) \\
3(27.3 \%)\end{array}$ & $0,03^{3} \#$ \\
\hline \multicolumn{5}{|l|}{ Smoking } \\
\hline $\begin{array}{l}\text { Yes } \\
\text { None }\end{array}$ & $\begin{array}{l}23(46 \%) \\
27(54 \%)\end{array}$ & $\begin{array}{l}19(48.7 \%) \\
20(51.3 \%)\end{array}$ & $\begin{array}{l}4(36.4 \%) \\
7(63.6 \%)\end{array}$ & $0.47^{2}$ \\
\hline \multicolumn{5}{|l|}{$\begin{array}{l}\text { Alcohol } \\
\text { Consumption }\end{array}$} \\
\hline $\begin{array}{l}\text { Yes } \\
\text { No }\end{array}$ & $\begin{array}{c}7(14 \%) \\
43(86 \%)\end{array}$ & $\begin{array}{c}5(12.8 \%) \\
34(87.2 \%)\end{array}$ & $\begin{array}{l}2(18.2 \%) \\
9(81.8 \%)\end{array}$ & $0.64^{3}$ \\
\hline
\end{tabular}


The results of the examination of cfDNA, CEA, and CA19-9 are presented in table 2. From 50 research subjects, it was found that cfDNA in research subjects had a median value of $59.71 \mathrm{ng} / \mathrm{mL}$, a minimum value of $8.43 \mathrm{ng} / \mathrm{mL}$, and a maximum value of 157.86 $\mathrm{ng} / \mathrm{mL}$. cfDNA values were found to be significantly higher in the group of patients with cancer. The group with cancer also had higher CEA and CA19-9 values than the group without cancer.

Table 2. Results of examination of tumor markers in both groups

\begin{tabular}{|c|c|c|c|c|}
\hline $\begin{array}{l}\text { Colorectal Tumor } \\
\text { Markers }\end{array}$ & $\begin{array}{c}\text { Subjects } \\
(n=50)\end{array}$ & $\begin{array}{c}\text { Colorectal Cancer } \\
(n=39)\end{array}$ & $\begin{array}{c}\text { Without Cancer } \\
(n=11)\end{array}$ & $\boldsymbol{p}$ \\
\hline cfDNA (ng/mL) & $59.71(8.43-157,86)$ & 66.57 (25.86-157.86) & $44(8.43-56.43)$ & $<0.001$ \\
\hline $\begin{array}{l}\text { CEA (ng/mL) } \\
\text { CA19-9 (U/mL) }\end{array}$ & $106(1.10-984)$ & $126(1.10-984)$ & $\begin{array}{l}2,20(1.10-42.50) \\
\quad 3.50(1.20-12)\end{array}$ & $\begin{array}{l}<0.001 \\
<0.001\end{array}$ \\
\hline
\end{tabular}

Distributed data abnormal with the Kolmogorov-Smirnov Test. The median difference test between cancer and no cancer groups with the test Mann-Whitney.

The results of the Spearman's rho test showed that there was a significant relationship between the levels of cfDNA and CEA $(\mathrm{p}=<0.001)$ with a strong positive correlation strength $(\mathrm{r}=0.635)$. Meanwhile, cfDNA and CA19-9 had a moderate correlation value $(r=0.572)$ which was statistically significant $(p=<0.001)$. The presentation of data regarding the correlation of cfDNA levels with CEA and CA19-9 in suspected colorectal cancer patients at Dr. Mohammad Hoesin Hospital Palembang can be seen in Table 3 and Figure 1 .

Table 3. Correlation between cfDNA levels with CEA and CA19-9 levels in research subjects

\begin{tabular}{|c|c|c|c|}
\hline \multicolumn{2}{|r|}{ Correlation relationship between } & \multirow{2}{*}{$\begin{array}{c}\mathbf{R} \\
0.635\end{array}$} & \multirow{2}{*}{$\begin{array}{c}\mathbf{p} \\
<0.001\end{array}$} \\
\hline cfDNA & CEA & & \\
\hline & CA19-9 & 0.572 & $<0.001$ \\
\hline
\end{tabular}

Spearman's rho test, the $\mathrm{p}$ value means if $\mathrm{p}<0.05$. Correlation strength is very weak if $\mathrm{r}<0.2$, weak if $\mathrm{r}=0.21-0.4$, medium if $r=0.41-0.6$, strong if $r=0.61-0.8$ and very strong if $>0.8$

\section{Correlation of cfDNA levels with serum CEA levels of patients suspected of colorectal cancer}

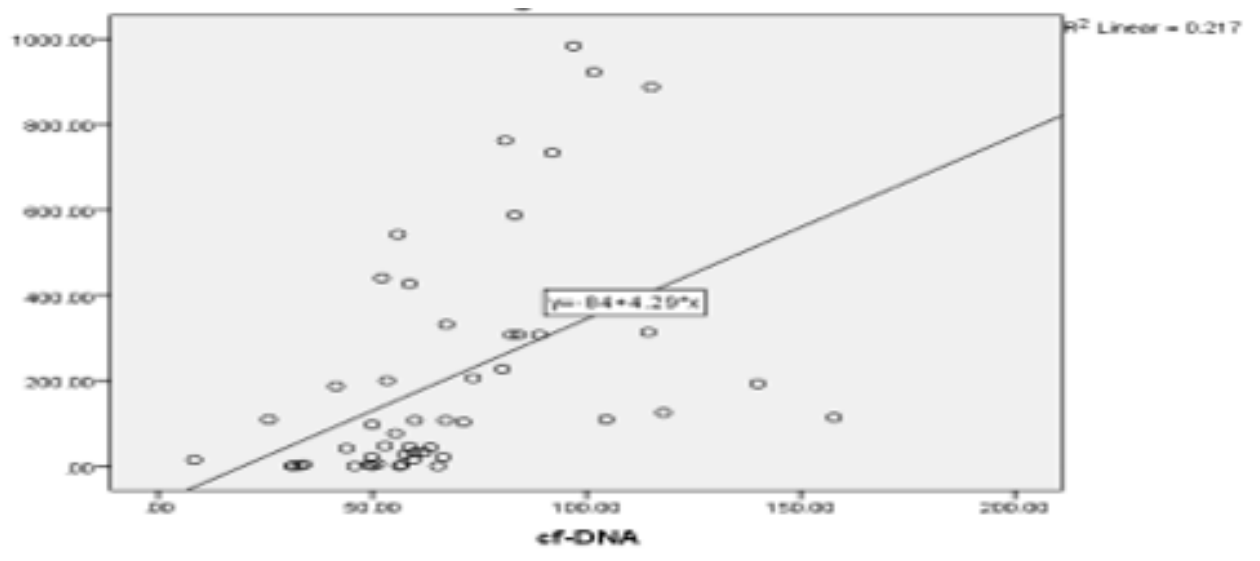




\section{Correlation of cfDNA levels with serum CA19-9 levels of patients suspected of colorectal cancer}

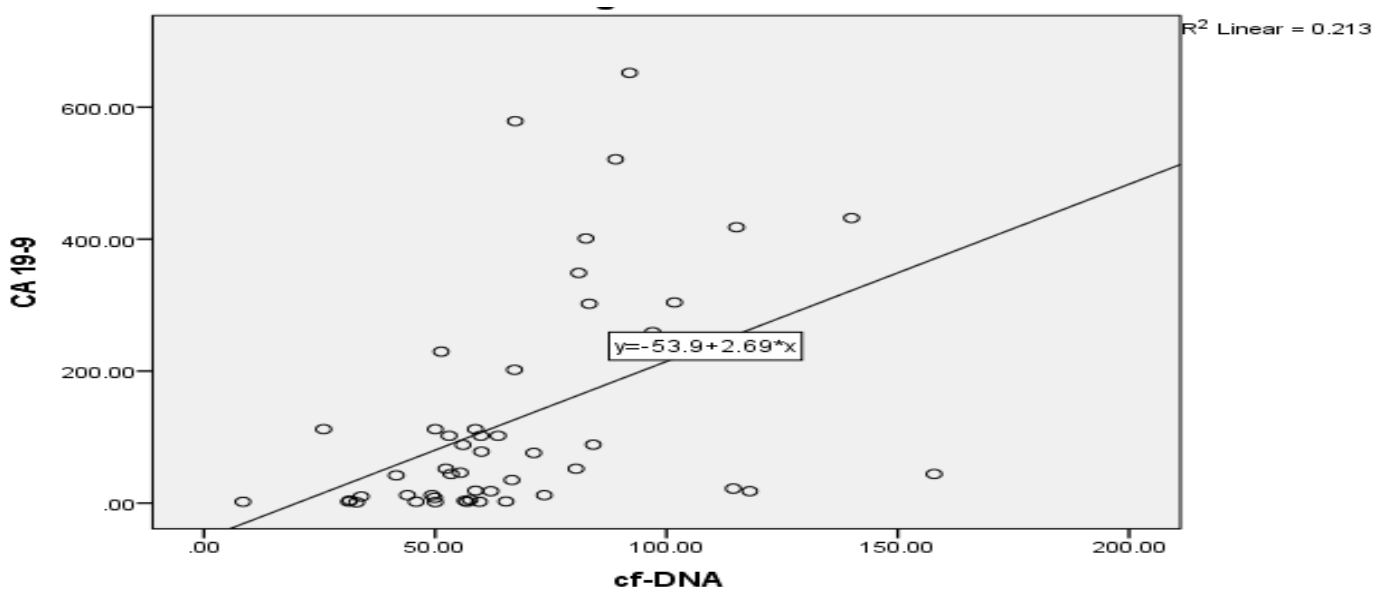

Figure 1. cfDNA correlation graph with CEA and CA19-9

Figure 2 shows that for cfDNA levels, the optimal cut-off point between sensitivity and specificity is at point 13 which when viewed in the analysis table is $50.64 \mathrm{ng} / \mathrm{dL}$ with sensitivity $92.3 \%$, specificity $90.9 \%$, positive predictive value $95.2 \%$, negativevalue $82.3 \%$, area under the curve predictive 0.945 and accuracy
92.4\%. The group of patients based on this level was the group with low serum cfDNA levels, namely $<50.64 \mathrm{ng} / \mathrm{mL}$ and the group with high serum cfDNA levels, $50.64 \mathrm{ng} / \mathrm{dL}$.

\section{Cut-Off cfDNA}

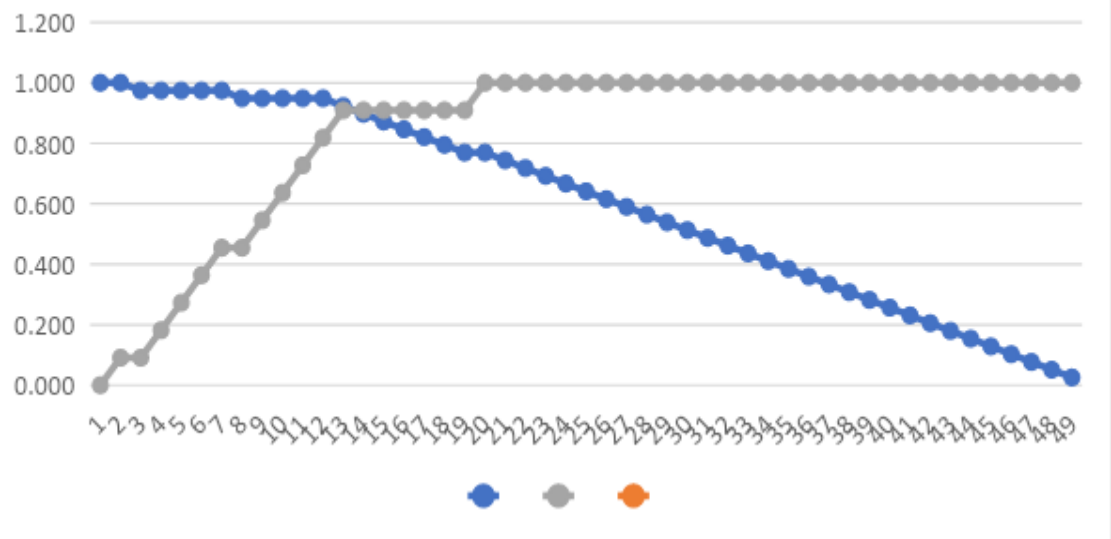

Figure 2. Cutoff point of serum cfDNA

Table 4. Diagnostic bivariate analysis of cfDNA compared to histopathological examination results in colorectal cancer diagnosis

\begin{tabular}{ccc}
\hline cfDNA & \multicolumn{2}{c}{ Colorectal Cancer } \\
\cline { 2 - 3 } (cutoff $50.64 \mathrm{ng} / \mathrm{mL})$ & Cancer & Without Cancer \\
\hline High cfDNA & $37(81.8 \%)$ & $2(5,2 \%)$ \\
\hline low cfDNA & $2(18.2 \%)$ & $9(94.8 \%)$ \\
\hline
\end{tabular}


Table 5. Diagnostic significance of cfDNA versus histopathological examination results in colorectal cancer diagnosis

\begin{tabular}{cc}
\hline Diagnostic Significance & Value (95\%CI) \\
AUC & $0.945(0.842-0.990)$ \\
Sensitivity & $92,3 \%(79.1 \%-98.4 \%)$ \\
Specificity & $90.9 \%(58.7 \%-99.8 \%)$ Prediction \\
PositiveValue & $95.2 \%(81.4 \%-99.7 \%)$ Prediction \\
Value Negative & $82.3 \%(48.7 \%-97.1 \%)$ \\
Accuracy & $92.4 \%(80.1 \%-97.4 \%)$ \\
\hline
\end{tabular}

To determine the diagnostic significance of CEA, CA19-9, compared with the diagnostic value of cfDNA was analyzed bivariate between each diagnostic marker examined. In addition, analysis with combination markers was also carried out to determine the diagnostic value compared to the histopathological examination results. The calculation results are shown in table 5 .

Table 6. Diagnostic significance between combination markers in colorectal cancer diagnosis

\begin{tabular}{ccccccc}
\hline Markers (cutof) & AUC & Sensitivity & Specificity & $\begin{array}{c}\text { Positive } \\
\text { predictive } \\
\text { value (PPV) }\end{array}$ & $\begin{array}{c}\text { Negative } \\
\text { predictive } \\
\text { value (NPV) }\end{array}$ & $\begin{array}{c}\text { Diagnostic } \\
\text { accuracy }\end{array}$ \\
\hline $\begin{array}{c}\text { cfDNA (50.64ng/mL) } \\
\text { CEA (25ng/ml) }\end{array}$ & 0.945 & $92,3 \%$ & $90.9 \%$ & $95.2 \%$ & $82.3 \%$ & $92.4 \%$ \\
CA19-9 (15U/ml) & 0.942 & $87.2 \%$ & $90.9 \%$ & $97.1 \%$ & $66.8 \%$ & $87.9 \%$ \\
cfDNA and CEA & 0.977 & $94.9 \%$ & $81.8 \%$ & $94.9 \%$ & $91.8 \%$ & $90.1 \%$ \\
cfDNA and CA19-9 & 0.988 & $87.2 \%$ & $100 \%$ & $100 \%$ & $64.2 \%$ & $90.1 \%$ \\
\hline
\end{tabular}

CfDNA, CEA, and CA19-9 examinations provide excellent AUC results with AUC's 0.945, 0.942, and 0.935, respectively. A combination examination of

\section{Discussion}

Findings El-Gayar et al who analyzed the accuracy of cfDNA in Egypt using the nanodrop method against ALU markers as in this study showed lower cfDNA levels with a median level of $4.6 \mathrm{ng} / \mathrm{mL}$ (range 1.1$48 \mathrm{ng} / \mathrm{mL}$ ). ${ }^{31}$ This difference in the distribution of values may be influenced by differences in the course of the patient's disease, differences in race, and differences in laboratory analysis methodologies. To date, there is no universally used cfDNA assay standard.

The cfDNA value was found to be significantly higher in the group of patients with colorectal cancer
cfDNA with CEA and cfDNA with CA19-9 provides better AUC examination results than cfDNA, CEA, or CA19-9 examinations themselves.

$(\mathrm{p}<0.001)$. The results are similar to those of El-Gayar et al., Mead et al., Hao et al., and Zaher et al. who found higher cfDNA in the colorectal cancer group than in the noncancerous lesion group and in healthy controls. ${ }^{31,40,51-52}$ Almost all previous reports using the ALU marker showed consistent results of significantly higher cfDNA levels in the colon cancer group than in the group without colon cancer. In healthy individuals, cfDNA is mostly derived from leukocytes. While in the case of cancer, cfDNA is likely derived from apoptosis and necrosis of cancer cells or surrounding cells and possibly through active release by cancer cells. ${ }^{53}$

CEA and CA 19-9 are the two major tumor markers 
for colorectal cancer. CEA is atumor marker broad spectrum and is one of the many markers used in colorectal cancer. This study showed that the group with colorectal cancer had higher CEA and CA19-9 values than the group without cancer. These results are consistent with the studies of Flamini et al, Qi et al, Hao et al, and El-Gayar et al, which also showed CEA and CA19-9 values in the colorectal cancer group were higher than in the non-cancer group. 31,49-50,53 Various studies have shown that an increase in serum CEA in colorectal cancer patients indicates a worse prognosis than in patients with normal CEA levels. CA19-9 was also found to be elevated in colorectal cancer. Shin Nishiumi et al explained that the expression of CA19-9 in colorectal cancer patients plays a role in the diagnosis of colorectal cancer. ${ }^{55}$ László Herszényi et al also concluded in their study that in some colorectal cancer patients, there was a continuous increase in serum levels of CEA and CA19-9 about 2-5 months before they were declared relapse or metastases. 56 The results of this study are consistent with various studies.

The results of the Spearman's rho correlation test showed that there was a significant relationship between cfDNA levels and CEA with a strong positive correlation strength. Meanwhile, cfDNA and CA19-9 had a statistically significant moderate correlation value. This result contradicts the findings of Qi et al in 2013 who reported a weak and insignificant correlation between cfDNA and CEA ( $\mathrm{r}=0.232, \mathrm{p}=0.210)$ and between cfDNA and CA19-9 ( $\mathrm{r}=-0.158, \mathrm{p}=0.397)$. Qi et al suggested that cfDNA may be an independent predictor of colonic carcinoma progression which was not correlated with CEA or CA19-9.

Salem et al's study in Egypt showed results that were in line with this study. ${ }^{67}$ The study showed a significant positive correlation between the DNA integrity index cfDNA markers of ALU and CEA, although the correlations proved tended to be weak $(\mathrm{r}=0.39, \mathrm{p}=0.03)$. The El-Gayar study also showed results in line with moderate correlations of cfDNA with CA19-9 (r=0.4, p<0.001) and CEA ( $\mathrm{r}=0.45, \mathrm{P}<0.001) .{ }^{31}$ This study has consistently shown that cfDNA correlates with CA19-9 and CEA so that cfDNA can be used as a tumor marker in the diagnosis of colorectal cancer.

\section{Conclusion}

In this study, cfDNA has excellent accuracy in diagnosing colorectal cancer.

\section{References}

1. Bray, F., Ferlay, J., Soerjomataram, I., et. al. Global cancer statistics 2020: GLOBOCAN estimates if incidence and mortality worldwide for 36 cancers in 185 countries. A Cancer Journal for Clinicians. 2020; 00(00): 1-30.

2. Rawla, P., Sunkara, T., dan Adam Barsouk. Epidemiology of colorectal cancer: incidence, mortality, survival, and risk factor. Gastroenterology Review. 2019; 14 (2): 89-103.

3. Goodarzi, E., Beiranvand, R., Naemi, H., Momenabadi, V., dan Z. Khazaei. Worldwide incidence and mortality of colorectal cancer and human development index (HDI): an ecological study. World Cancer Research Journal. 2019: e1433(6): 1-8.

4. Onyoh, E. F., Hsu, W. F., Chang, L. C., et. al. The rise of colorectal cancer in Asia: epidemiology, screening, and management. Curr Gastroenterol Rep. 2019: 21(36): 1-10.

5. Wong, M. C. S., Ding, H., Wang, J., Chan, P. S. F., dan Junjie Huang. Prevalence and risk factors of colorectal cancer in Asia. Intest Res. 2019; 17(3): 317-329.

6. Rex, D. K., Boland, R., Dominitz, J. A., et. al. Colorectal cancer screening: Recommendations for physicians and patients from the U.S. multi-society task force on colorectal cancer. Gastrointestinal Endoscopy. 2017; 86(1): 18- 33.

7. Dekker, E., Tanis, P. J., Vleugels, J. L.A., Kasi, P. M., dan Michael B Wallace. Colorectal cancer. The Lancet. 2019; 394: 1467-1480.

8. Sung, J. J. Y., Ng, S. C., Chan, F. K. L., Chiu, H. M., et. al. An updated Asia Pasific consensus recommendations on colorectal cancer. Gut. 2014; 0: 1-12. 
9. Kim, S. E., Paik, H. Y., Yoon, H., et. al. Sex and gender disparities in colorectal cancer risk. World J Gastroenterol. 2015; 21(17): 51675175.

10. Kuipers, E. J., Grady, W. M., Lieberman, D., et. al. Colorectal cancer. Nature Review: Disease Primers. 2015; 12(1): 1-25.

11. Markowitz, S. D., dan Monica M. Bertagnolli. Molecular basis of colorectal cancer. N Engl J Med. 2009; 361(25): 2449-2460.

12. Menteri Kesehatan Republik Indonesia. Keputusan Menteri Kesehatan Republik Indonesia Nomor HK.01.07/MENKES/406/2018 tentang Pedoman Nasional Pelayanan Kedokteran Kanker Kolorektal.

13. Ordonez-Mena, J. M., Walter, V., Schottker, B., et. al. Impact of prediagnostic smoking and smoking cessation on colorectal cancer prognosis: a meta-analysis of individual patient data from cohort within the CHANCES consortium. Annals of Oncology. 2018; 29: 472-483.

14. Tiwari, A., Saraf, S., Verma, A., Panda, P. K., dan Sanjay K. Jain. Novel targeting approach and signaling pathways of colorectal cancer: An insight. World J Gastroenterol. 2018; 24 (39): 4428-4435.

15. Fleming, M., Ravula, S., Tatishchev, S. F., dan Hanlin L. Wang. Colorectal carcinoma: pathological aspect. J Gastrointest Oncol. 2012; 3(3): 153-173.

16. Szar, Dan H dan Lombard, Martin. The Large Intestine: dalam Basic Science Crash Course Gastrointestinal System. 2012; 4: 73-98.

17. Mohammad Amin Pourhoseingholu. Epidemiology and burden of colorectal cancer in Asia Pacific region: what shall we do now?. Transl Gastrointest Cancer. 2014; 3(4): 169173.

18. Byon, J. S., Yang, S. K., Kim, T. I., et. al. Colorectal neoplasm in asymptomatic Asians: a prospective multinational multicenter colonoscopy survey. Gastrointestinal
Endoscopy. 2007; 65(7): 1015-1022.

19. Andres, S. F., Williams, K. N., dan Anil K. Rustgi. The molecular basis of metastatic colorectal cancer. Curr Colorectal Cancer Rep. 2018; 1-11.

20. Weiser, Martin R. AJCC 8th edition: Colorectal cancer. Ann Surg Oncol. 2018; 25: 1454-1455.

21. Jessup, J. M., Goldberg, R. M., Asare, E. A., et. al. Colon and rectum; dalam The AJCC Cancer Staging Manual, 8th edition. Springer. 2018; 251-272.

22. Tong, G. J., Zhang, G. Y., Liu, J., et. al. Comparison of the eight version of the American Joint Committee on Cancer manual to the seventh version for colorectal cancer: a retrospective review of our data. World J Clin Oncol. 2018; 9(7): 148-161.

23. Jelski, W., dan Barbara Wroczko. Biochemical markers of colorectal cancer - present and future. Cancer Management and Research. 2020; 12: 4789- 4797.

24. Wang, X., Shi, X. Q., Zeng, P.W., Mo, F. M., dan $\mathrm{Zi}$ Hua Chen. Circulating free DNA as the diagnostic marker for colorectal cancer: a systematic review and meta-analysis. Oncotarget. 2018; 8(36): 24514-24524.

25. Liu, Z., Zhang, Y., Niu, Y., et. al. A systematic review and meta-analysis of diagnostic and prognostic serum biomarkers of colorectal cancer. Plos One. 2014; 9(8): 1-13.

26. Oh, H. H., dan Young Eun Joo. Novel biomarkers for the diagnosis and prognosis of colorectal cancer. Intest Res. 2020; 18(2): 168183.

27. Nikolau, S., Qiu, S., Fiorentina, F., et. al. Systematic review of blood diagnostic markers in colorectal cancer. Techniques in Coloproctology. 2018; 22: 481-498.

28. Danese, E., Montagnana, M., dan Giuseppe Lippi. Circulating molecular biomarkers for screening or early diagnosis of colorectal cancer: which is ready for prime time?. Ann Transl Med. 2019; 7(21): 1-12.

29. Chen, B., Xia, Z., Deng, Y. N., et. al. Emerging 
microRNA biomarkers for colorectal cancer diagnosis and prognosis. Open Biol. 2019; 9: $1-11$.

30. Vymetalkova V, Cervena K, Bartu L, Vodicka P. Circulating Cell-Free DNA and Colorectal Cancer : A Systematic Review. Published online 2018. doi:10.3390/ijms 19113356

31. El-Gayar D, El-Abd N, Hassan N, Ali R. Increased free circulating DNA integrity index as a serum biomarker in patients with colorectal carcinoma. Asian Pacific J Cancer Prev. 2016; 17(3): 939-944. doi:10.7314/APJCP.2016.17.3.939

32. Xu X, Niu M, Zhang B, Chang J, Su F, Wang K. Clinical value of CEA and CA19-9 in colorectal cancer by Kaplan-Meier survival curve. 2019; 12(12): 13305-13310.

33. Spindler KG. Methodological, biological and clinical aspects of circulating free DNA in metastatic colorectal cancer. Published online 2021. doi:10.1080/0284186X.2016.1253861

34. Basnet S, Zhang ZY, Liao WQ, Li SH, Li PS, Ge HY. The prognostic value of circulating cell-free DNA in colorectal cancer: A meta-analysis. J Cancer. 2016; 7(9): 1105-1113. doi: $10.7150 /$ jca. 14801

35. Shi H, Li Q, Liao J, et al. Different primers for diagnosing circulating cell-free DNA of colorectal cancer. Transl Cancer Res. 2020; 9(5): 3435-3442. doi:10.21037/tcr-19-2017

36. Hauptman N, Glavač D. Colorectal Cancer Blood-Based Biomarkers. Gastroenterol Res Pract. $2017 ; 2017$. doi:10.1155/2017/2195361

37. Li T, Qian Y, Li H, Deng J. Combination of serum lipids and cancer antigens as a novel marker for colon cancer diagnosis. Published online. 2018: 1-7.

38. Zhang SY, Lin M, Zhang HB. Diagnostic value of carcinoembryonic antigen and carcinoma antigen 19-9 for colorectal carcinoma. Int $\mathrm{J}$ Clin Exp Pathol. 2015; 8(8): 9404-9409.

39. Salem R, Ahmed R, Shaheen K, Abdalmegeed $\mathrm{M}$, Hassan H. DNA integrity index as a potential molecular biomarker in colorectal cancer. 2020; 4.

40. Gonzalez-Pons M, Cruz-Correa M. Colorectal Cancer Biomarkers: Where Are We Now? Biomed Res Int. 2015; 2015(Table 1). doi:10.1155/2015/149014

41. MD A, MD P, MD P, et al. Highly sensitive diagnostic method for colorectal cancer using the ratio of free DNA fragments in serum. Fujita Med J. 2019; 5(1):14-20. doi:10.20407/fmj.2017-025

42. Wang X, Shi X-Q, Zeng P-W, Mo F-M, Chen ZH. Circulating cell free DNA as the diagnostic marker for colorectal cancer: a systematic review and meta-analysis. Oncotarget. 2018; 9(36): 24514-24524. doi:10.18632/oncotarget. 25314

43. Shi H, Li Q, Liao J, et al. Different primers for diagnosing circulating cell-free DNA of colorectal cancer. Transl Cancer Res. 2020; 9(5): 3435-3442. doi:10.21037/tcr-19-2017

44. Hufnagl C, Leisch M, Weiss L, et al. Evaluation of circulating cell-free DNA as a molecular monitoring tool in patients with metastatic cancer. Oncol Lett. 2020; 19(2): 1551-1558. doi:10.3892/ol.2019.11192

45. Bhangu JS, Taghizadeh $\mathrm{H}$, Braunschmid $\mathrm{T}$, Bachleitner-Hofmann T, Mannhalter C, Circulating cell-free DNA in plasma of colorectal cancer patients - A potential biomarker for tumor burden, Surgical Oncology (2017), doi: 10.1016/j.suronc.2017.08.001.

46. Siegel, R. L., Fedewa, S. A., Anderson, W. F., Miller, K. D., Ma, J., Rosenberg, P. S., \& Jemal, A. Colorectal cancer incidence patterns in the United States, 1974-2013. JNCI: Journal of the National Cancer Institute. 2017; 109(8).

47. Bradbury, K. E., Murphy, N., \& Key, T. J. Diet and colorectal cancer in UK Biobank: a prospective study. International journal of epidemiology. 2020; 49(1), 246-258.

48. Botteri, E., Iodice, S., Bagnardi, V., Raimondi, S., Lowenfels, A. B., \& Maisonneuve, P. 
Smoking and colorectal cancer: a metaanalysis. Jama. 2008; 300(23), 2765-2778.

49. Hao, T. B., Shi, W., Shen, X. J., Qi, J., Wu, X. H., Wu, Y., ... \& Ju, S. Q. Circulating cell-free DNA in serum as a biomarker for diagnosis and prognostic prediction of colorectal cancer. British journal of cancer. 2014; 111(8): 14821489.

50. Qi, J., Qian, C., Shi, W., Wu, X., Jing, R., Zhang, L., ... \& Ju, S. Alu-based cell-free DNA: a potential complementary biomarker for diagnosis of colorectal cancer. Clinical biochemistry. 2013; 46(1-2), 64-69.

51. Zahir, M. N., Azhar, E. M., Rafiq, S., Ghias, K., \& Shabbir-Moosajee, M. (2014). Clinical features and outcome of sporadic colorectal carcinoma in young patients: a cross-sectional analysis from a developing country. International Scholarly Research Notices, 2014.

52. Mead, R., Duku, M., Bhandari, P., \& Cree, I. A. Circulating tumour markers can define patients with normal colons, benign polyps, and cancers. British journal of cancer. 2011; 105(2): 239-245.

53. Petit, J., Carroll, G., Gould, T., Pockney, P., Dun, M., \& Scott, R. J. Cell-free DNA as a diagnostic blood-based biomarker for colorectal cancer: a systematic review. Journal of Surgical Research. 2019; 236: 184-197.
54. Flamini, E., Mercatali, L., Nanni, O., Calistri, D., Nunziatini, R., Zoli, W., ... \& Amadori, D. Free DNA and carcinoembryonic antigen serum levels: an important combination for diagnosis of colorectal cancer. Clinical Cancer Research. 2006; 12(23), 6985-6988.

55. Nishiumi, S., Kobayashi, T., Ikeda, A., Yoshie, T., Kibi, M., Izumi, Y., ... \& Yoshida, M. A novel serum metabolomics-based diagnostic approach for colorectal cancer. PloS one. 2012; $7(7)$, e40459.

56. HERSZÉNYI, László, et al. Tumor marker utility and prognostic relevance of cathepsin B, cathepsin L, urokinase-type plasminogen activator, plasminogen activator inhibitor type1, CEA and CA 19-9 in colorectal cancer. BMC cancer, 2008; 8.1: 1-12.

57. Salem, R., Ahmed, R., Shaheen, K., Abdalmegeed, M., \& Hassan, H. DNA integrity index as a potential molecular biomarker in colorectal cancer. Egyptian Journal of Medical Human Genetics. 2020; 21(1): 1-9.

58. 58. Umetani, N., Kim, J., Hiramatsu, S., Reber, H. A., Hines, O. J., Bilchik, A. J., \& Hoon, D. S. Increased integrity of free circulating DNA in sera of patients with colorectal or periampullary cancer: direct quantitative $\mathrm{PCR}$ for ALU repeats. Clinical chemistry. 2006; 52(6): 1062-106. 